\title{
PROTECTION OF CULTURAL HERITAGE: RISK MANAGEMENT IN MUSEUMS IN TURKEY
}

\author{
Kültürel Mirasın Korunması: Türkiye'deki Müzelerde Risk Yönetimi
}

Nevra ERTÜRK*

\section{ABSTRACT}

The concept of risk management has started to be used in museums towards the end of 1980's and it has been suggested that an analytical approach could be used for risks in preventive conservation work. Risk management has started to be discussed as a separate area of study in museums in Turkey with 1999 earthquakes. In this context, the aim of the article is to examine the studies carried out on risk management in museums in Turkey and assess the current situation; to explain the risk management needs of museums based on this review and to make suggestions. In the article, risks about museum buildings and collections will be explained at first; information on the legal regulations, strategies, action plans, institutional initiatives and projects related to risk management in museums in Turkey will be given by examining the existing documents and the studies carried out in this field; risk management work both in state and private museums will be examined and suggestions will be made for the needs of museums related to risk management. In the article, laws, regulations and reports related to the subject were examined with the document analysis method, and the studies in the field were searched with the literature review. According to the research findings, the activities carried out on risk management in museums in Turkey are mostly limited with earthquake risk and preventive conservation. In the current legal regulations, there is a need to refer to the issue of risk management for museums. Risk management policies and plans should be developed for museums and holistic studies, which cover all risk factors, should be carried out accordingly. An institutional structuring, which can give service in the national scale on risk management issue for all moveable and immoveable cultural properties, museums, libraries and archives, is a need.

Keywords: museology, cultural heritage, risk management, museums, museums in Turkey.

\footnotetext{
* Assoc. Prof. Dr., Yildiz Technical University, Faculty of Architecture, Department of Conservation and Restoration of Cultural Property, İstanbul/Turkey. E-mail: nevra.erturk@gmail.com. ORCID: 0000-0001-8389-1280.
} 


\section{öz}

Risk yönetimi kavramı müzelerde 1980'lerin sonlarına doğru kullanılmaya başlanmış olup, önleyici koruma çalışmalarında riskler için analitik bir yaklaşımın kullanılabileceği önerilmiştir. Risk yönetimi, Türkiye'deki müzelerde ayrı bir çalışma alanı olarak 1999 depremleri ile tartışımaya başlanmıştır. Bu çerçevede makalenin amacı; Türkiye'deki müzelerde risk yönetimi ile ilgili gerçekleştirilen çalışmaları incelemek ve durum tespitinde bulunmak; bu incelemeye dayanarak müzelerin risk yönetimi ile ilgili ihtiyaçlarını açıklamak ve öneriler sunmaktır. Makalede öncelikle müze binaları ve koleksiyonlarla ilgili riskler açıklanacak; mevcut dokümanların ve bu alanda gerçekleştirilen çalışmaların incelenmesi ile Türkiye'deki müzelerde risk yönetimi ile ilgili yasal düzenlemeler, stratejiler, eylem planları, kurumsal girişimler ve projeler hakkında bilgi verilecek; hem devlet müzeleri hem de özel müzelerdeki risk yönetimi çalışmaları incelenerek, müzelerin risk yönetimi ile ilgili ihtiyaçları için önerilerde bulunulacaktır. Makalede, doküman analizi yöntemi ile konuyla ilgili kanun, yönetmelik ve raporlar incelenmiş, literatür taraması ile alandaki çalışmalar araştırılmıştır. Araştırma bulgularına göre, Türkiye'deki müzelerde risk yönetimi ile ilgili yürütülen faaliyetler çoğunlukla deprem riski ve önleyici koruma ile sınırlıdır. Mevcut yasal düzenlemelerde müzelerde risk yönetimi konusuna atıfta bulunulmasına ihtiyaç vardır. Müzeler için risk yönetimi politikaları ve planları geliştirilmeli ve bu kapsamında tüm risk faktörlerini içeren bütüncül çalışmalar yapılmalıdır. Ulusal ölçekte tüm taşınır ve taşınmaz kültür varlıkları ile müzeler, kütüphaneler ve arşivler için risk yönetimi alanında hizmet verecek kurumsal bir yapılanmaya ihtiyaç vardır.

Anahtar Sözcükler: müzebilim, kültürel miras, risk yönetimi, müzeler, Türkiye müzeleri.

\section{Introduction}

Today, the main functions of museums are; conservation, research and communication. In the period starting from the first foundations of museums until the present time, the scope of conservation function has been expanded and the conservation work, which began with remedial conservation, continued with preventive conservation, disaster and emergency management, and risk management. The topic of risk management in the area of cultural heritage does not only cover risks related to museums, but also risks related to all moveable and immoveable cultural properties from historical sites to monuments, archaeological sites to collections in libraries and archives.

Museum buildings and collections face ten different risks as physical forces, fire, water, criminals, incorrect relative humidity, incorrect temperature, light and ultraviolet (UV), pollutants, pests and dissociation (Pedersoli 
et al., 2016: 27). Risks caused by climate change, terrorist attacks, epidemics are accepted as new generation risks for museums in the 21st century.

The concept of risk management in the area of cultural heritage has been first used by United Nations Educational, Scientific and Cultural Organization (UNESCO) at the end of World War II. This concept has started to be mentioned in museums for the first time towards the end of 1980's. In fact, it has been suggested that an analytical approach could be used for the risks in preventive conservation studies. ${ }^{1}$ In the 1990's, activities on risk management in museums gained momentum and Jonathan AshleySmith's book titled Risk Assessment for Object Conservation (1999) has become an important source for museums on this subject (Waller, 2003: 11).

In case of Turkey, the first study carried out on risk management in museums is related to earthquake risk. Pre-studies and scientific research have been carried out between the years 1992-1998 on the protection of collections on display from the effects of earthquakes and reports have been written. The 1999 Kocaeli and Düzce earthquakes have become a breaking point in terms of earthquake risk management in museums and the damages received by museum buildings and collections in exhibition and storage areas due to earthquakes has especially brought the issue of risk management within the scope of earthquake risk to the fore.

In this article, the concept of risk management and risks related to museums are explained; information on the legal regulations, strategies, action plans, institutional initiatives and projects at national level are given; the studies undertaken within the scope of risk management both in state and private museums in Turkey are summarized and the needs of museums in the area of risk management are shared and suggestion are made.

\section{The Concept of Risk Management and Risks Related to Museums}

The concept of risk management is used within a very wide framework from the finance sector to the energy, construction and health sectors. Risk is defined as "the combination of the probability of an event and its negative consequences" (URL-1). Risk management is a process management involving the definition of risks by doing a context assessment about museum buildings and collections, risk identification, risk analysis, evaluating the risks, treat and monitor (Pedersoli et al., 2016: 16). The purpose is reducing damage and increasing the coping capacity. Museum staff and visi-

${ }^{1}$ See (Waller \& Shelton, 1989; Baer, 1991). 
tors should also be taken into consideration in carrying out risk management work in museums.

Museums have primary risks based on the region they are located in. While earthquakes, fires or floods are the primary risks for some museums, wars, theft or vandalism can be the primary risks for others. Risks related to museums are listed as follows in the literature: 1. Physical forces (earthquake, war, armed conflict, incorrect handling, construction work, etc.), 2. Fires (faulty electrical installations or equipment, gas leaks, arson, careless acts while smoking, fire spreading from other building(s) nearby, construction and/or renovation work, etc.), 3. Water (rain, tsunami, flood, storm, tornado, water leakage from the roof, doors and windows, faulty water and sewage pipes inside/outside the museum building, firefighting, etc.), 4. Criminals (thieves and vandals), 5. Incorrect relative humidity (local climate, ground water, inadequate air conditioning, leakage from doors and windows, cold walls, etc.), 6. Incorrect temperature (local climate, sunlight, incandescent lamps, heaters, etc.), 7. Light and ultraviolet (UV) (sun, electrical light sources, no film coating on skylights or windows, faulty lighting systems, etc.), 8. Pollutants (air pollution, industries, vehicles, leakage from roofs, doors and windows, compounds which are out from exhibition and storage furniture or packing materials, visitors, restoration materials that contaminate the object, etc.), 9. Pests (insects, rodents, birds, bats, sources of food and nesting materials attract pests, etc.), 10. Dissociation (lack of inventory, poor documentation, misplacing objects, no regular maintenance and supervision in exhibition and storage areas, etc.). (Pedersoli et al., 2016: 26-46).

Earthquake, fire or flood are risks which happen suddenly and can have great impacts if mitigation efforts are not taken. On the other hand, incorrect relative humidity, incorrect temperature, pollutants or pests are risks that progress slower and their effects on collections appear in a longer period of time.

The cycle of risk management in museums consists of preventive conservation, response and recovery stages and the preventive conservation work constitute the most important stage in this cycle. Within the framework of preventive conservation work in museums, regular cleaning, periodic maintenance and control should be made; accurate and complete inventory records of all the objects in collections should be kept; documents related to the museum building and its location, disaster history and security of the collections should be kept in the museum documentation 
system; policies, plans, principles and standards about the protection and safety of the building and the collections should be prepared and the most suitable physical and environmental conditions should be provided for collections. Within the framework of the museum risk management, primarily the museum director, facility manager, conservator-restorer, documentation expert, curator and collection manager, security and cleaning staff should work in cooperation.

\section{The Legal Situation, Strategies and Action Plans}

In Turkey, state museums are affiliated to the Presidency and the Ministry of Culture and Tourism. On the other hand, private museums are affiliated to public and private institutions, real and legal persons such as municipalities, military, banks, universities, companies, foundations, ministries other than the Ministry of Culture and Tourism.

Main legal regulations regarding the museums in Turkey are: International Council of Museums (ICOM) Turkish National Committee Regulation $(1970)^{2}$, Law on the Conservation of Cultural and Natural Property No: 2863 $(1983)^{3}$, Regulation on Private Museums and their Supervision (1984) and Museums Internal Services Regulation (1990). On the other hand, some of the state and private museums have separate regulations. These are: Regulation on Military Museums (1984), Regulation on Painting and Sculpture Museums (2010), Presidential Decree on National Palaces Administration (2018). In addition to the legal regulations, Museum Studies Guide (2001) for the Ministry of Culture and Tourism's museums is also in effect. Although there are explanations on conservation and security in the aforementioned documents, there is no information on risk management issue both for state and private museums.

Today, risk management is one of the main components of museums' conservation work. In Turkey, the highest authority related to the conservation and restoration of the collections in state museums is the General Directorate of Cultural Properties and Museums under the Ministry of Culture and Tourism. The central and regional laboratories ${ }^{4}$ affiliated to the General

\footnotetext{
${ }^{2}$ Some articles of the regulation were changed in 1985.

${ }^{3}$ Some articles of the law were amended in 1987, 2004, 2006, 2009, 2011, 2013, 2016-2018.

${ }^{4}$ Istanbul Restoration and Conservation Central and Regional Laboratories Directorate was established within the body of the Ministry of Culture in 1984 and the laboratories directorate became active in 1985. Regional restoration and conservation laboratories are established in the cities of Ankara, Antalya, Bursa, Diyarbakır, Erzurum, Gaziantep, Izmir, Nevşehir, Trabzon and have started to provide service by 2012.
} 
Directorate carry out the conservation-restoration process on behalf of the Ministry. When there is a need, private museums can receive support from the central and regional laboratories as well. However, the concept of risk management is not defined among the primary work area of the laboratories in the Restoration and Conservation Central and Regional Laboratories Directorates' Regulation on Procedures and Principles (2019).

Although there is no reference to risk management in museums in the legal regulations, the issue is mentioned in strategies or action plans. For instance; in the strategic aim statements of Proposal Report on the Management and Operation Model for Turkish Museums, prepared by Istanbul 2010 European Cultural Capital Agency Cultural Heritage and Museums Directorate (2010), the necessity for risk analysis studies for museums was underlined and risk management planning was proposed multiple times under the headings of security in museums and collection management (Istanbul 2010 Avrupa Kültür Başkenti Ajansı Kültürel Miras ve Müzeler Direktörlüğü, 2010: 27, 93, 95, 120, 136, 141).

In the National Earthquake Strategy and Action Plan dated 2012-2023, prepared by the Ministry of Interior, Disaster and Emergency Management Presidency, there is an article related to museums. According to the article, it is targeted to develop methods to reduce the vulnerability of museum collections against earthquake and building disaster museums in cities subject to large earthquakes and/or organize exhibitions to increase awareness in the society about earthquakes (URL-2: 47, 54, 80-81).

Lastly, concept of risk management in museums came to the agenda in the action plan of the $3^{\text {rd }}$ National Cultural Council held in 2017. In the action plan, it was proposed to establish a disaster and risk management system for museums. It is aimed to develop disaster and risk management as well as emergency response action plans for museums in cooperation with relevant institutions and organizations, especially Disaster and Emergency Management Presidency units and law enforcement agencies, and to carry out training programs related to the topic (Kültür ve Turizm Bakanlığı, 2017: 16).

When the aforementioned strategies and action plans are evaluated, it has been determined that a few number of risk analysis for museums have been realized, however, risk management planning both for each state and private museums is needed. On the other hand, Turkey has become one of the leading countries in the world with its knowledge, expertise and experi- 
ence on earthquake risk mitigation methods of museum collections as it is stated in the National Earthquake Strategy and Action Plan. After 1999 earthquakes, a few number of disaster museums are opened in cities subject to large earthquakes such as Izmit or Adapazarı, and exhibitions are organized to increase awareness in the society about earthquakes as it is also mentioned in the National Earthquake Strategy and Action Plan. Disaster and risk management as well as emergency response action plans for museums are needed as it is stated in the action plan of the $3^{\text {rd }}$ National Cultural Council. Various training programs related to the disaster, emergency or risk management for museums were carried out by different institutions or organizations such as Bogazici University, Yildiz Technical University, International Council on Monuments and Sites (ICOMOS) International Scientific Committee on Risk Preparedness (ICORP) Turkey, Friends of Cultural Heritage (FOCUH), after 1999 earthquakes.

\section{Institutional Initiatives and Projects Related to Risk Management}

In Turkey, the institutional initiatives on museums and risk management are mostly related to earthquake risk and preventive conservation work and a small number of studies deal with risk factors and risk analysis other than earthquake risk.

The first study on risk management in museums has been carried out by Bogazici University, Kandilli Observatory and Earthquake Research Institute, Earthquake Engineering Department in 1992 and a pre-study and a report have been prepared on the protection of the objects on display in museums. A similar research project was done by the Earthquake Engineering Department in 1994 and a scientific research project has been carried out between the years 1996-1998 supported by UNESCO which was titled Identification of the Mitigations for the Protection of Objects on Display in Museums from the Impact of Earthquakes (Erdik et al., 2010: 100). With the 1999 Kocaeli and Düzce earthquakes, the subject of risk management in Turkish museums has come to the fore and,

after the 1999 earthquakes and in particular in Istanbul, numerous trainings, seminars and scientific meetings have been held and additionally, scientific projects, reports and publications were prepared on the earthquake risk management for museum buildings and collections with the purpose of drawing attention to the vulnerability and earthquake risk of historical buildings (Ertürk, 2015: 38). 
"In 2000, Disaster Preparedness Education Project (DPEP) ${ }^{5}$ has been created within the framework of a five-year program funded by the United States Agency for International Development's Office of Foreign Disaster Assistance (USAID/OFDA)" (URL-4); and educational activities have been organized within the framework of Non-Structural Risk Mitigation which if one of the four training programs related to the museums.

In 2003, the research project titled, Seismic Conservation of Historical and Cultural Treasures of a World City: Sizing the Need and Formulating an Action Plan for the Museums of Istanbul, with the support of World BankProVention Consortium was conducted. The scope of the project is; to develop risk identification forms, to carry out risk analysis work with museum experts in selected state and private museums' exhibition and storage areas in Istanbul, to organize an educational seminar and to develop a training CD on the topic (Sungay \& Ertürk, 2005: 186).

Another study which involves museums is the Research, Training and Implementation Protocol on Reducing the Earthquake Risk of Cultural Properties (URL-5) between Bogazici University, Yildiz Technical University, Istanbul Technical University and Mimar Sinan Fine Arts University in 2004, with the knowledge and support of the Ministry of Culture and Tourism, and with the purpose of developing the strategies, policies and projects in terms of the foundation of a national institute planned to carry out all sorts of research, training and implementation cooperation to be done jointly and be active in this area to reduce the earthquake risk which threatens cultural properties. Within the scope of the protocol, which is the result of a long period of work and cooperation, no activities have been organized.

In 2006, the project titled, Protection of Museum Items Against Earthquake Shaking by Low-Cost Base Isolation Devices, with the support of World Bank-ProVention Consortium. The purpose of the project is to develop low cost "Ball-in-Cone" type isolation units with standard shape and bearing capacity which can be used for objects exhibited and stored in museums (Önem et al., 2006).

\footnotetext{
${ }^{5}$ On October, 2004, with the decision of Kandilli Observatory and Earthquake Research Institute Board of Directors, the Disaster Preparedness Training Unit was established within the institute, and existing training programs, new trainings and projects to be developed within the scope of DPEP were aimed to gain a corporate identity. The name of the Disaster Preparedness Training Unit was changed to Disaster Preparedness Laboratory in January 2020 (URL-3).
} 
The same year, Istanbul Seismic Risk Mitigation and Emergency Preparedness Project (ISMEP) was developed within the body of the Governorship of Istanbul. The project which was managed by Istanbul Project Coordination Unit (IPCU) deals with the required preparations prior to, during and after the disaster, besides supportive and preventive implementations related to risk reduction, response and recovery. Within the scope of ISMEP, the inventory of all the buildings which are under the supervision of the Ministry of Culture and Tourism were taken and the earthquake performance evaluation studies for Istanbul Archaeology Museum's classic and additional buildings, Hagia Irene and Topkapi Palace Mecidiye Mansion were completed and a project proposal was developed on structural strengthening against earthquakes for each building (Istanbul Valiligi IPKB \& AFAD, 2014: 42, 78).

ICORP Turkey ${ }^{6}$, founded in 2011 with the purpose of carrying out activities on reducing the damage of disasters, preparedness, response and recovery in terms of protecting and managing cultural properties specific to monuments, protected areas, museums, libraries and archives. Within this framework, ICORP Turkey organizes scientific meetings, trainings and makes publications.

In 2011-2012, the project titled Scientific Techniques and Risk Management in Museums (STERM-MUSEE) within the scope of EU-Turkey Intercultural Dialogue: Non-Governmental Services, Museums Grant Scheme was carried out under the coordination of the Ministry of Culture and Tourism, project ownership of Museum of Anatolian Civilization and in partnership with ICOM and FOCUH. Within the scope of the project activities, an international conference and training program were organized in 2012, titled Risk Management in Museums (Aydın \& Zoroğlu, 2012: 10).

In 2016, Guide for Management of Earthquake Risks for Historical Structures is prepared with the cooperation of the General Directorate for Foundations and Istanbul Governorships' IPCU.? Within the scope of this study, the management cycle of integrated disasters risks for cultural heritage was developed. ${ }^{8}$ The guide is efficient for museum buildings that are refunctionalized from historical structures.

\footnotetext{
${ }^{6}$ See (URL-6).

${ }^{7}$ See (Vakıflar Genel Müdürlüğü \& Istanbul Valiliği IPKB, 2017).

${ }^{8}$ For the details of the management cycle of integrated disasters risks for cultural heritage see (Ünal, 2019).
} 


\section{Risk Management in State and Private Museums}

Throughout the historical process, museums in Turkey have been faced with different types of risk, primarily earthquake risk. On the other hand, information and documentation is limited in terms of the extent of the damage, what kind of damages took place due to different types of risks, what type of mitigation efforts were taken or what kind of response and recovery actions were carried out. Although there are records about physical or environmental factors in the condition reports related to museum building and collections and security reports exist in some museums, there are no risk management documentation or database that cover state and private museums in Turkey. Although there is a disaster and emergency plan in almost all of the museums in Turkey, a small number of museums such as palaces, pavilions or kiosks affiliated to the Presidency or military museums such as Harbiye Military Museum or Istanbul Naval Museum update these plans and drills are carried out within certain intervals.

According to the information given by Hakan Melih Aygün (interview, 22.01.2021), Project Coordinator of the Museums National Inventory System, Ministry of Culture and Tourism, it is very important to have a complete documentation system in order to have a successful risk management work in museums. Hence, documentation work was initiated in museums under the name of Museums National Inventory System by the Ministry of Culture and Tourism in 2019. Data entries are planned to be completed significantly by the end of 2023 .

The most important and recent data about the damages received by museums belongs to the 1999 earthquakes. "It is known that Museum of Turkish and Islamic Art, Topkapi Palace Museum, Dolmabahçe Palace, Istanbul Archaeology Museums' annex building and Istanbul Painting and Sculpture Museum's former building in Istanbul have been affected in structural and non-structural scales in the 1999 Kocaeli Earthquake" (Erdik et al., 2010: 98).

On the other hand, a risk management work which embodies different risk factors and all of the stages of risk management in state and private museums has not been carried out yet. The existing studies are mostly about earthquake risk and involve preventive conservation work. The only study which involves different risk factors has been carried out for Beylerbeyi Palace in Istanbul. This study has been carried out within the 
scope of a doctorate thesis and focuses on risk analysis and risk preparedness stages. ${ }^{9}$

Mitigations have been taken in certain museums in Turkey, primarily the museums in Istanbul, against earthquake risk in the exhibition and storage areas of museums. "Istanbul Archaeology Museums, Topkapi Palace Museum, Sadberk Hanim Museum, Rahmi Koc Museum, Dolmabahce Palace, Beylerbeyi Palace, Sakip Sabanci Museum" (Erdik et. al., 2010: 102103), Museum of Anatolian Civilizations, Antalya Museum and Ephesus Museum are among these museums.

With the information gathering form prepared within the scope of a post-doctoral research on Reducing Earthquake Risk to Museum Collections in Turkey carried out in 2008-200910, it has been aimed to collect data about museum buildings, collections, staff, disaster history and experience and earthquake preparedness. The information gathering form has been sent to 92 state museums and answers have been received from 73 museums. According to the obtained data, 39 museums reported that they fastened their cabinet and shelf systems; 35 museums reported that they boxed the objects in their storage areas to protect them from earthquakes; 32 museums reported that they fastened their showcases; 26 museums reported that they put barriers in front of their open shelf storage systems; 19 museums reported that they fastened the objects with supports and monofilaments in their exhibition areas; 14 museums reported that they placed padding material between objects to prevent them from hitting into each during an earthquake and 13 museums reported that they decreased the number of objects on display (Ertürk, 2009: 207). After this postdoctoral research, a comprehensive survey has not been conducted on museums and different risk factors in Turkey.

Although risk management in museums is an interdisciplinary work, staff who will conduct risk management work are mainly conservatorsrestorers with an expertise on risk management. Conservators-restorers are employed in a small number of museums such as Museum of Anatolian Civilizations, Mardin Museum or Troya Museum among the museums affiliated with the Ministry of Culture and Tourism. With the establishment of regional restoration and conservation laboratories since 2012, periodic con-

\footnotetext{
${ }^{9}$ See (Kuzucuoğlu, 2016). This study was carried out within the scope of a doctoral dissertation (2011) and published in 2016.

${ }^{10}$ It was realized by Nevra Ertürk with the support of the Turkish Cultural Foundation.
} 
trols on physical and environmental conditions of exhibition galleries and storage areas of the state museums affiliated to the Ministry have gained momentum. Additionally in the last decade, while the existing museum buildings, exhibition and storage areas of the state museums have been renewed, new museum buildings have also started to be built. Thus, the new museum buildings are constructed by taking into consideration of earthquake risk. Since conservation experts are employed in the museums affiliated to the Presidency and military, preventive conservation works are carried out periodically. Thereby, risk factors such as incorrect relative humidity, incorrect temperature, pollutants or pests that progress slower, are kept under control in state and military museums.

The situation in private museums varies according to the budget of the museum, the number of staff and the size of the collection. Conservatorsrestorers employed in a few private museums such as Istanbul Painting and Sculpture Museum, Sadberk Hanim Museum, Rahmi M. Koc Museum or Sakip Sabanci Museum, whereas large and medium scale private museums mostly procure external conservation-restoration services. Therefore, preventive conservation work, which is an important part of the risk management, is not carried out efficiently.

As a result, risk management work that includes all risk factors and all of the stages of risk management cycle has not been carried out in both state and private museums yet. While there is a disaster and emergency plan in almost all of the museums in Turkey, there is no separate risk management policy or plan.

\section{Conclusion}

Based on the research questions of the article, there are institutional initiatives, strategies, action plans, researches or projects on risk management in museums in Turkey. However, all items mentioned in the strategic goals and action plans need to be implemented.

Risk management policies and plans are needed in order to disseminate the risk management work throughout the country. Data related to risk management can be involved in Museum National Inventory System. Thereby, the data contributes both to scientific researches and projects.

While carrying out risk management work in museums, curators, collection managers, documentation experts, facility managers, security, cleaning and the administrative staff should work in cooperation with the conservators-restorers; costs should be calculated in the light of data ob- 
tained as a result of risk analysis and the implementation stage should be initiated in view of the priorities and the budget of the museum. When the risk preparedness stage is more accurate, it lowers the risk of the museum that will face in case of an emergency situation or a disaster.

The existing disaster and emergency plans should be updated; drills should be carried out with certain intervals and risk analysis studies, which will differ in line with the locations, buildings, collections, physical and environmental conditions and needs of museums, should be conducted.

Although there is a sufficient amount of human resources to carry out risk management work in Turkish museums, conservators-restorers need to specialize in the area of risk management. The workload of museum staff or central and regional restoration and conservation laboratories' staff are too much. Within this framework, there is a need to give references to the subject of risk management in legal regulations at first; to initiate a unit on risk management for cultural properties including museums within the body of Disaster and Emergency Management Presidency or Ministry of Culture and Tourism in order to coordinate and implement risk management work related to museums throughout Turkey.

\section{References}

Aydın, Mahmut \& Zoroğlu, Candemir (2012). Müzelerde Bilimsel Teknikler ve Risk Yönetimi - Scientific Techniques and Risk Management in Museums. Ankara: Anadolu Medeniyetleri Müzesi Yayınları.

Baer, Norbert S. (1991). "Assessment and Management of Risks to Cultural Property". Science, Technology and European Cultural Heritage: Proceedings of the European Symposium (Bologna, 13-16 June 1989). Ed. N. S. Baer, C. Sabbioni, A. I. Sors. UK: Butterworth-Heinemann Publishers, 27-36.

Erdik, Mustafa et al. (2010). "Earthquake Risk Mitigation in Istanbul Museums". Natural Hazards, 53: 97-108.

Ertürk, Nevra (2009). "Seismic Conservation of State Museum Collections in Turkey". International Conference on Vulnerability of the $20^{\text {th }}$ Century Cultural Heritage to Hazards and Preventive Measures (City of Leros, 22-24 April 2009). Greece, 203-209.

Ertürk, Nevra (2015). "Müzecilik Perspektifinden UNESCO Dünya Miras Listesi'ndeki Alanlarda Deprem Risk Yönetimi”. Mimar.ist, 54: 34-40. 
İstanbul 2010 Avrupa Kültür Başkenti Ajansı Kültürel Miras ve Müzeler Direktörlüğü (2010). Türkiye Müzeleri Için Yönetim ve Iş̧letim Modeli Öneri Raporu. İstanbul: İstanbul 2010 Avrupa Kültür Başkenti Ajansı Yayınları.

Kuzucuoğlu, Alpaslan Hamdi (2016). Bütünleşik Müze Yönetimi: Beylerbeyi Sarayında Risk Analizleri ve Koruyucu Tedbir Önerileri. İstanbul: Hiperlink Yayınları.

Kültür ve Turizm Bakanlığı (2017). III. Milli Kültür Şurası Eylem Planı: Kültür Varlıkları, Müzeler ve Arkeoloji. İstanbul, 1-50.

Önem, Göktürk et al. (2006). "Protection of Museum Items Against Earthquake Shaking By Low-Cost Base-Isolation Devices". $4^{\text {th }}$ World Conference on Structural Control and Monitoring (San Diego, 11-13 July 2006). USA: University of Southern California, n.p.

Pedersoli, José Luiz et al. (2016). A Guide to Risk Management to Cultural Heritage. ICCROM and Government of Canada, Canadian Conservation Institute.

Sungay, Bilgen \& Ertürk, Nevra (2005). "Seismic Conservation of Cultural Treasures in the Museums of Istanbul”. Know Risk. England: United Nations and Tudor Rose, 186-187.

Ünal, Zeynep Gül (2019). "Kültür Varlıklarına Yönelik Bütünleşik Afet Risklerinin Yönetiminde Acil Müdahale Evresi”. Kültür Varlıklarına Yönelik Afet Risklerinin Yönetimi. Ed. Zeynep Gül Ünal ve Nevra Ertürk. İstanbul: İstanbul Tarihi Alanları Alan Başkanlığı Yayınları, 14-24.

Vakıflar Genel Müdürlüğü \& İstanbul Valiliği iPKB (2017). Tarihi Yapılar Iç̧in Deprem Risklerinin Yönetimi Kılavuzu. Ankara: Vakıflar Genel Müdürlüğü Yayınları.

Waller, R. Robert \& Shelton, S. (1989). "Risk Management Strategies Applied to the Development of Pragmatic Solutions to Collection Storage Problems". SPNHC $4^{\text {th }}$ Annual Meeting, Programme and Abstracts (Calgary, 23-28 July 1989). Canada: AB Canada and University of Calgary, 32.

Waller, R. Robert (2003). Cultural Property Risk Analysis Model: Development and Application to Preventive Conservation at the Canadian Museum of Nature. Göteborg: Acta Universitatis Gothoburgensis.

\section{Electronic Resources}

URL-1: "UNISDR Terminology on Disaster Risk Reduction". https://www. preventionweb.net/files/7817_UNISDRTerminologyEnglish.pdf (Access: 23. 04.2021). 
URL-2: “Ulusal Deprem Stratejisi ve Eylem Planı 2012-2023”. https://deprem.afad.gov.tr/downloadDocument?id=1643 (Access: 23.04.2021).

URL-3: "Afete Hazırlık Laboratuvarı". http://www.koeri.boun.edu.tr/aheb /tarihce.asp_(Access:: 22.04.2021).

URL-4: "Bogazici University Kandilli Observatory Earthquake Research Institute Disaster Preparedness Education Unit”. http://www.koeri.boun. edu.tr/aheb/dpeu_english.pdf (Access: 22.04.2021).

URL-5: "Müzelerde Deprem Riski ve Riskin Azaltılması Üzerine Düşünceler". http://v3.arkitera.com/h28903-muzelerde-deprem-riski-ve-riskinazaltilmasi-uzerine-dusunceler.html (Access: 23.04. 2021).

URL-6: "ICORP Türkiye Hakkında". http://www.icorpturkiye.org/ (Access: 22.04. 2021).

The following statements are made in the framework of "COPE-Code of Conduct and Best Practices Guidelines for Journal Editors":

Ethics Committee Approval: Ethics committee approval is not required for this study.

Declaration of Conflicting Interests: The author has no potential conflict of interest regarding research, authorship or publication of this article. 